\title{
Comunicação
}

[Communication]

\section{Serum survey for antibodies to coronavirus, herpesvirus, calicivirus, and parvovirus in domestics cats from Rio Grande do Sul, Brazil}

[Inquérito sorológico para anticorpos contra coronavírus, herpesvírus, calicivírus e parvovírus em gatos domésticos do Rio Grande do Sul, Brasil]

\author{
J.M. Johann, C.F. Caetano, R. Hass, T.N. Guim, G. Fischer, \\ G.D. Vargas, T. Vidor, S.O. Hübner ${ }^{*}$ \\ Faculdade de Veterinária - UFPel \\ Campus Universitário \\ 96010-900 - Pelotas, RS
}

In Brazil, data regarding the occurrence of feline infections by Feline coronavirus (FCoV), Feline herpesvirus (FHV-1), Feline calicivirus (FCV), and Feline parvovirus (FPV) are scarce (Weiblen et al., 1988; Oliveira et al., 2003; Ruthner et al., 2005), and to this moment there are no scientific reports made in the region of Pelotas, RS, Southern Brazil. FCoV is associated to the development of mild enteritis (Vennema et al., 1998; Hartmann, 2005) or, when FCoV mutants are originated, it can lead to the development of a feline infectious peritonitis (FIP), a progressive systemic disease with a wide spectrum of clinical signs and high mortality rate (Hartmann, 2005). FHV-1 and FCV are agents causing mainly upper respiratory tract diseases, but cats can be infected by these agents without showing clinical signs and become persistent carriers (Maggs et al., 1999; Radford et al., 2007). FPV is highly contagious, inducing an acute disease characterized by leukopenia, fever, depression, dehydration, diarrhea, and vomiting (McKnight et al., 2007).

The present study investigated the presence of antibodies against FCoV, FHV-1, FCV, and FPV in the serum samples of 97 domestic cats from Pelotas, Rio Grande do Sul, Southern Brazil. The antibody frequency was analyzed regarding information about age, gender, and habitat that would allow contact with other animals. Serum samples were collected from animals that would be submitted to elective surgeries at the Veterinary Hospital at the Universidade Federal de Pelotas, RS and in five private clinics from the region, from August 2005 to October 2006. Blood samples were collected by cephalic or jugular vein puncturing and sent to the virology and immunology laboratory of UFPel where they were centrifuged for serum separation. The sera were submitted to serum neutralization test (SN) according to Hohdatsu et al. (1999), with a few modifications. Serum serial dilutions from 1:4 to 1:256 were incubated with $100 \mathrm{TCID}_{50}$ of the virus to which the presence of neutralizing antibodies was investigated. The viruses were supplied by the virology laboratory at the Universidade Federal de Santa Maria and Institute Desidério Finamor. The serum and virus mixture was incubated at $37^{\circ} \mathrm{C}$ for $1 \mathrm{~h}$ and then a suspension with approximately 30,000 CRFK cells containing $20 \%$ of bovine fetal serum was added to each well. The plates were incubated at $37^{\circ} \mathrm{C}$ in atmosphere with $5 \% \mathrm{CO}_{2}$ for three to seven days. The readings were made when the 100 TCID $_{50}$ was observed in the control cells.

Samples were obtained from cats aging from two-month old to 17-year old. From 97 cats analyzed, 33 (34\%) were male, 64 (66\%) female, and $81(83.5 \%)$ mixed breed. Regarding age, 28 animals $(28.8 \%)$ were less than one-year old, 41 (42.2\%) from one to five-year old; nine (9.3\%) were older than five-year old, and 19 cats

Recebido em 17 de outubro de 2008

Aceito em 19 de março de 2009

*Autor para correspondência (correspoonding autor)

E-mail: sohubner@yahoo.com.br 
$(19.6 \%)$ were of unknown age. Forty-five cats (46.4\%) were housed of which $15(33.3 \%)$ had limited access to the streets (they lived in apartments); 17 (17.5\%) lived in the streets, and $35(36.1 \%)$ had no information about habitat. There was previous vaccination history against FHV-1, FCV and FPV, with at least one dose, for 11 cats $(11.3 \%)$.

The SN results indicated that the majority of the cats were exposed to multiple agents $(71.1 \%)$, and only $15.5 \%$ of the samples were negative for all the viruses. Antibodies against $\mathrm{FCoV}$ were detected in $75.2 \%(73 / 97)$ of the cats. Such antibodies represent natural exposure to the virus, as in Brazil there is no vaccine against FCoV commercially available. This high level is comparable to the ones described in cats that live in places of relative high population density (Addie and Jarret, 2003) and it can be explained by the fact that most of the cats has frequent access to the streets and, therefore, probable contact with other cats. A large proportion of cats infected by FCoV can intermittently shed the virus in the feces and by this way the virus is kept in the environment allowing infection of susceptible animals (Foley et al., 1997). For FHV-1, there were antibodies in $38.1 \%(37 / 97)$ of the animals: $73 \%(8 / 11)$ of the vaccinated, $39.2 \%(20 / 51)$ of the unvaccinated, and $25.7 \%$ $(9 / 35)$ of the cats with unknown vaccination history. Antibodies against FCV were present in $56.7 \%(55 / 97)$ of the animals: $81.8 \%(9 / 11)$ of the vaccinated cats, $52.9 \% \quad(27 / 51)$ of the unvaccinated, and $54.3 \%(19 / 35)$ of the cats with unknown vaccination history. The levels found for FHV-1 and FCV are similar to the ones reported in other countries (Lappin et al., 2002) and it can be explained by the existence of carriers; FCV carriers continuously discharge the virus while FHV carriers discharge it intermittently and the virus is latent most of the time (Maggs et al., 1999). For FPV, there were antibodies in $69.1 \%(67 / 97)$ of the animals: $100 \%(11 / 11)$ of the vaccinated, $66.6 \%(34 / 51)$ of the unvaccinated, and $62.8 \%(22 / 35)$ of the cats with unknown vaccination history. FPV is usually shed in the feces for a short period of time after infection, but it remains viable in the environment for several months (Scott, 1980). Then, infection in most of the animals may have happened due to environmental exposure.

There was a higher frequency of seropositivity for all the viruses analyzed among adult animals (older than one-year) comparing to young animals (Table 1). This fact may be a result of behavior differences; usually adult animals have higher migratory activity which allows more contact with other animals. Similarly, there was a tendency to a higher number of seropositives among animals that live in places which allows free contact with other animals. There was no difference in seropositivity between males and females.

Table 1. Antibodies to feline coronavirus (FCoV), feline herpesvirus (FHV-1), feline calicivirus (FCV), and feline parvovirus (FPV) in the serum of 97 cats regarding age, gender, habitat, and vaccination history

\begin{tabular}{|c|c|c|c|c|c|c|c|c|c|c|c|c|c|}
\hline \multirow{2}{*}{ Virus } & \multirow{2}{*}{$\begin{array}{c}\text { Number } \\
(\%)^{1}\end{array}$} & \multicolumn{3}{|c|}{ Age (years) } & \multicolumn{2}{|c|}{ Gender } & \multicolumn{4}{|c|}{ Habitat } & \multicolumn{3}{|c|}{ Vaccination history } \\
\hline & & $<1$ & $1-10$ & UA & Male & Female & Apt & $\mathrm{HS}$ & Street & HNI & Unvaccinated & Vaccinated & UV \\
\hline $\mathrm{FCoV}$ & $\begin{array}{c}73 \\
(75,2)\end{array}$ & $\begin{array}{c}18 \\
(24,6)\end{array}$ & $\begin{array}{c}41 \\
(56,2)\end{array}$ & $\begin{array}{c}14 \\
(18,6)\end{array}$ & $\begin{array}{c}25 \\
(34,2)\end{array}$ & $\begin{array}{c}48 \\
(65,7)\end{array}$ & $\begin{array}{c}12 \\
(16,9)\end{array}$ & $\begin{array}{c}22 \\
(30,1)\end{array}$ & $\begin{array}{c}12 \\
(16,9)\end{array}$ & $\begin{array}{c}27 \\
(37)\end{array}$ & $\begin{array}{c}73 \\
(100)\end{array}$ & 0 & 0 \\
\hline FHV-1 & $\begin{array}{c}37 \\
(38,1)\end{array}$ & $\begin{array}{c}2 \\
(5,4)\end{array}$ & $\begin{array}{c}26 \\
(70,3)\end{array}$ & $\begin{array}{c}9 \\
(24,3)\end{array}$ & $\begin{array}{c}14 \\
(37,8)\end{array}$ & $\begin{array}{c}23 \\
(62,2)\end{array}$ & $\begin{array}{c}5 \\
(13,5)\end{array}$ & $\begin{array}{c}13 \\
(35,1)\end{array}$ & $\begin{array}{c}3 \\
(8,1)\end{array}$ & $\begin{array}{c}16 \\
(43,2)\end{array}$ & $\begin{array}{c}20 \\
(54,1)\end{array}$ & $\begin{array}{c}8 \\
(21,6)\end{array}$ & $\begin{array}{c}9 \\
(24,3)\end{array}$ \\
\hline FCV & $\begin{array}{c}55 \\
(56,7)\end{array}$ & $\begin{array}{c}6 \\
(11)\end{array}$ & $\begin{array}{c}36 \\
(65,4)\end{array}$ & $\begin{array}{c}13 \\
(23,6)\end{array}$ & $\begin{array}{c}18 \\
(32,7)\end{array}$ & $\begin{array}{c}37 \\
(67,2)\end{array}$ & $\begin{array}{c}10 \\
(18,2)\end{array}$ & $\begin{array}{c}15 \\
(27,2)\end{array}$ & $\begin{array}{c}8 \\
(14,5)\end{array}$ & $\begin{array}{c}22 \\
(40)\end{array}$ & $\begin{array}{c}27 \\
(49,1)\end{array}$ & $\begin{array}{c}9 \\
(16.4)\end{array}$ & $\begin{array}{c}19 \\
(34,5)\end{array}$ \\
\hline FPV & $\begin{array}{c}67 \\
(69,1) \\
\end{array}$ & $\begin{array}{c}12 \\
(18) \\
\end{array}$ & $\begin{array}{c}41 \\
(61,2) \\
\end{array}$ & $\begin{array}{c}14 \\
(20,9) \\
\end{array}$ & $\begin{array}{c}26 \\
(38,8) \\
\end{array}$ & $\begin{array}{c}41 \\
(61,2) \\
\end{array}$ & $\begin{array}{c}8 \\
(11,9) \\
\end{array}$ & $\begin{array}{c}23 \\
(34,3) \\
\end{array}$ & $\begin{array}{c}9 \\
(13,4) \\
\end{array}$ & $\begin{array}{c}27 \\
(40,3) \\
\end{array}$ & $\begin{array}{c}34 \\
(50,7) \\
\end{array}$ & $\begin{array}{c}11 \\
(16,4)\end{array}$ & $\begin{array}{c}22 \\
(32,8) \\
\end{array}$ \\
\hline
\end{tabular}

Tnumber of seropositive animals and values in percentage in parenthesis.

UA: unknown age; Apt: apartment; HS: house with free access to the streets; HNI: habitat not informed; UV: unknown vaccination.

The results suggest high FCoV, FHV-1, FCV, and FPV exposure in the population of cats in the studied area. This indicates the need for further studies in order to evaluate the impact of the infections caused by these viruses in the cat population, as well as to propose and evaluate preventive measures.

Keywords: cat, virusis, antibodies, immunity 


\section{RESUMO}

A ocorrência da infecção por coronavírus felino (FCoV), herpesvírus felino tipo 1 (FHV-1), calicivírus felino (FCV) e parvovírus felino (FPV) foi investigada mediante a detecção de anticorpos no soro de 97 gatos domésticos de Pelotas, RS, pelo teste de soro-neutralização. Entre os animais estudados, 51 não eram vacinados, 11 haviam sido vacinados contra FHV-1, FCV e FPV com pelo menos uma dose, e 35 tinham histórico de vacinação desconhecido. Foram detectados anticorpos para o FCoV em 75,2\% (73/97) dos gatos. Anticorpos contra o FHV-1 estavam presentes em 38,1\% (37/97): 73\% (8/11) dos gatos vacinados, 39,2\% (20/51) dos não vacinados e 25,7\% (9/35) dos gatos com histórico de vacinação desconhecido. Anticorpos para o FCV estavam presentes em 56,7\% (55/97): 81,8\% (9/11) dos gatos vacinados, 52,9\% (27/51) dos não vacinados, e 54,3\% (19/35) dos gatos com histórico de vacinação desconhecido. Para o FPV, havia anticorpos em 69,1\% (67/97): 100\% (11/11) dos vacinados, 66,6\% (34/51) dos não vacinados e 62,8\% (22/35) dos gatos com histórico de vacinação desconhecido. Os resultados sugerem alta exposição ao FCoV, FHV-1, FCV e FPV na população de gatos na área estudada.

Palavras-chave: gato, viroses, anticorpos, imunidade

\section{REFERENCES}

ADDIE, D.; JARRETT, J.O. Persistence and transmission of natural type I feline coronavirus infection. J. Gen. Virol., v.84, p.2735-2744, 2003.

FOLEY, J.E.; POLAND, A.; CARLSON, J. et al. Patterns of feline coronavirus infection and fecal shedding from cats in multiple-cat environments. J. Am. Vet. Med. Assoc., v.210, p.1307-1312, 1997.

HARTMANN, K. Feline infectious peritonitis. Vet. Clin. N. Am. Small Anim. Pract., v.35, p.3979, 2005.

HOHDATSU, T.; SATO, K.; TAJIMA, T. et al. Neutralizing feature of commercially available feline calicivirus (FCV) vaccine immune sera against FCV field isolates. J. Vet. Med. Sci., v.61, p.299-301, 1999.

LAPPIN, M.R.; ANDREWS, J.; SIMPSON, D. et al. Use of serologic tests to predict resistance to feline herpesvirus 1 , feline calicivirus, and feline parvovirus infection in cats. J. Am. Vet. Med. Assoc., v.220, p.38-42, 2002.

MAGGS, D.J.; LAPPIN, M.R.; REIF, J.S. et al. Evaluation of serologic and viral detection methods for diagnosing feline herpesvirus-1 infection in cats with acute respiratory tract or chronic ocular disease. J. Am. Vet. Med. Assoc., v.214, p.502-507, 1999.
McKNIGHT, C.A.; MAES, R.K.; WISE, A.G. et al. Evaluation of tongue as a complementary sample for the diagnosis of parvoviral infection in dogs and cats. J. Vet. Diagn. Invest., v.19, p.409-413, 2007.

OLIVEIRA, F.N.; BUSS, M.S.; MELLO, T. et al. Peritonite infecciosa felina: 13 casos. Cienc. Rural, v.33, p.905-911, 2003.

RADFORD, A.D.; COYNE, K.P.; DAWSON, S. et al. Feline calicivirus. Vet. Res., v.38, p.319335, 2007.

RUTHNER, B.H.B.; KINDLEIN, V.F.; FRANCO, A.C. et al. Neutralizing antibodies against feline herpesvirus type 1 in captive wild felids of Brazil. J. Zoo. Wildl. Med., v.36, p.447450, 2005.

SCOTT, F.W. Virucidal disinfectants and feline viruses. Am. J. Vet. Res., v.41, p.410-414, 1980.

VENNEMA, H.; POLAND, A.; FOLEY J. et al. Feline infectious peritonitis viruses arise by mutation from endemic feline enteric coronaviruses. Virology, v.243, p.150-157, 1998.

WEIBLEN, R.; RAISER, A.G.; RAHAL, S.C. et al. Isolation of feline calicivirus from cats in Brazil. Vet. Rec., v.122, p.94-95, 1988. 